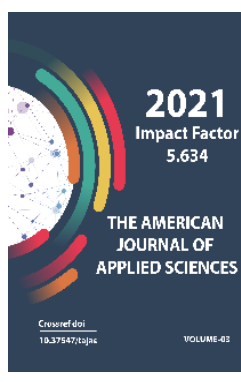

Journal Website: http://usajournalshub.c om/index,php/tajas

Copyright: Original content from this work may be used under the terms of the creative commons attributes 4.0 licence.

\section{Pedagogical Mechanisms Of The Formation Of The Social Outlook Of Future Teachers In The Context Of The Informatization Of Education}

\author{
Sidikova Zulfiyaxon Murodjon Qizi \\ Lecturer Of The Department Of Primary Education Methodology Of Fergana State University, \\ Uzbekistan
}

\title{
ABSTRACT
}

The formation of the right outlook for the future teachers is an important aspect of higher education system since the provision of theoretical knowledge is not enough for those students to become competent teachers who can manage the class successfully. The following article looks into the formation of mindset in future teachers.

\section{KEYWORDS}

Pedagogy, professional worldview, classification criteria, innovative teaching.

\section{INTRODUCTION}

Currently, the problem of forming a professional and pedagogical worldview is actually normal, because past years of change in education make you take a fresh look at the personality ness of the teacher. Today the teacher must not just good to know and be able to teach study your subject, be able to develop and implement educational discipline, but also perform a number of other actions activities aimed at shaping motivation to learn, to be brought up by children of patriotism, love for the Fatherland, tolerance, to create goodwill- atmosphere for learning. also in teacher's responsibilities include designing the 
creation and creation of situations that develop emotional and value sphere of the child (culture of experiences and value orientation of the child). Today education redefines its main task whose upbringing of personality and citizen, and this means the formation of school first of all value orientations. Thus, it becomes it is clear that the formation of value landmarks can only be achieved professional, master of his craft, teaching body with a formed professional and pedagogical world view. Formation problem professional and pedagogical the outlook of students future teachers is directly related to the formation of professionally pedagogical value system.

Values are backbone component, "content core" the worldview of the individual, and the cheat, directly affect other components of the worldview of the individual.

The problem of forming a professional and pedagogical worldview students - future teachers of is considered important both socially and a pedagogical problem, since outgoing in modern society, change requires teaching the head of the school had certain qualities, was morally developed, focused on reproduction removal and creation of values, defining sharing the meaning of human life, orienting tending him to spiritual and practical mastering reality.

Science has come to understand that values are the tool with the help of which you a range of attitudes towards the world and towards people. Names but values are a guideline for personality in society, allow the implementation make moral choices. Value The "base" of the future teacher is being formed as a result of his interaction with comes from which he "gets" values.
Currently, there are two directions for the development of teacher education - traditional and innovative. In our research, we rely on both directions, but we prefer the traditional innovative: it is based on taking into account real changes in the nature of the public demand for the individual and the changing role of the individual in the social process. Traditional education is characterized by a disciplinary model of education, which is distinguished by the fundamentalization of education, which, of course, is very important and relevant. However, the ongoing socioeconomic transformations require more pragmatism in the field of education. This is possible with a systematic and active approach to the study of academic subjects. This factor is manifested to a greater extent in the innovative direction. We believe that a reasonable combination of fundamentalization with pragmatism can modernize the model for the formation and development of a teacher's professional and pedagogical worldview. We are implementing this approach in our study.

Traditional teaching technologies include lectures, practical exercises, laboratory exercises, course work, thesis, teaching practice, and independent work. Innovative pedagogical technologies include: problembased learning, concentrated learning, modular learning, developmental learning, differentiated learning, active (contextual) learning, game learning.

There are various classifications of educational technologies. AND I. Savelyev classifies technologies according to their direction of action; by learning objectives; on the subject environment; by the technical means used; on a methodological task. V.F. Basharin proposes to classify technologies on the basis of generality and applied orientation. 
Generalized pedagogical technologies are defined by him as "synthetic theories built on certain psychological and pedagogical foundations"; applied (specific) pedagogical technologies are those that, at the methodological level, solve the problem of constructing a vocational training process aimed at achieving a pre-planned result.

In the practice of universities, all generalized pedagogical technologies are used to one degree or another. The dominance of a particular approach is determined by the type of institution, the goals of training, the commitment of teachers to certain pedagogical concepts. Unfortunately, in pedagogy there is no classification of generalized pedagogical technologies and the development of a system of applied technologies on their basis.

Let us dwell on the characteristics and analysis of traditional and innovative pedagogical technologies that actualize the process of formation and development of the professional worldview of a primary school teacher. In our opinion, in the system of lifelong pedagogical education, both traditional and innovative pedagogical technologies should be used in a reasonable combination. Therefore, we do not reject the traditional direction, especially well-proven forms and methods of teaching, which solve a wide class of didactic problems in this direction. These are forms of organization and forms of control. Various forms of organization and control of the educational process carry different functional loads in the formation and development of the teacher's professional and pedagogical worldview.

Lectures provide replenishment of information resources, seminars, practical classes contribute to the "crystallization" of cultural and value attractors, laboratory studies, practice, pedagogical tests stimulate the mobilization of adaptive and communicative resources of the professional and pedagogical worldview, the inner activity of the individual, leading to a restructuring and qualitative change in its worldview.

The integrativeness of the professional and pedagogical worldview requires the use of adequate teaching methods and excludes the use of a local method focused on the formation or development of some particular traits. The teaching method itself, therefore, must be multifunctional. Specific methods, note A.M. Matyushkin and A.A. Ponukalin, are planned depending on the choice of psychological mechanisms for securing the formed connections, which are determined by the initial motivational characteristics of the trainees.

One of the means of implementing an innovative direction in the practice of professional training of students and advanced training of teaching staff are active teaching methods (technologies of active or contextual learning). A.A. Verbitsky gave a definition of contextual learning as a conceptual basis for the integration of various types of student activities: educational, scientific, practical. Scientists have identified the forms of organizing students' activities in contextual learning: educational activities of academic type - quasi-professional activities - educational and professional activities. A special role in contextual learning is played by active forms and methods of learning or active learning technologies (TAO), which rely not only on the processes of perception, memory, attention, but, first of all, on creative, productive thinking, behavior, communication. 
Technologies are called active, since the roles of the learner, learners, and information change significantly in them. The classification of active learning technology is based on two features: the presence of a model (subject or process of activity) and the presence of roles (the nature of communication between students). On the basis of recreation (imitation) of the context of professional activity, its model representation in teaching, all active learning technologies are divided into non-imitation and imitation technologies. Nonimitative ones do not imply the construction of models of the studied phenomenon, process or activity. Activation is achieved here by selecting the problematic content of training, using in a special way the organizational procedure for conducting a lesson, using technical means and ensuring dialogical interactions between a teacher and a student. To non-imitative forms and methods, we attributed a problem lecture, a practical lesson with a "brainstorming", coursework, thesis. The listed teaching technologies create opportunities not only to transmit certain information to students, but to create prerequisites for the formation and development of a professional and pedagogical worldview.

Simulation methods and forms are based on imitation or imitation-game modeling, that is, reproduction in learning conditions with varying degrees of adequacy of the processes occurring in a real system. The construction of models and the organization of work with students make it possible to reflect in the educational process various types of professional context, to form and develop a professional-pedagogical worldview in conditions of quasi-professional activity.
In accordance with the second classification criteria - the presence of roles - a game procedure is proposed in working with the model, that is, the communication of students with each other and with teachers in the process of imitation. On this basis, all imitation technologies are divided into gaming and nongaming. Non-play forms and methods include specific situations (CS).

\section{REFERENCES}

1. M.J. Abdullaev. Methodology of application games in the training of young athletes // European Journal of Research and Reflection in Educational Sciences Vol. 8 No. 11, 2020 ISSN 2056-5852. 115-122 pg. http://www.idpublications.org/wpcontent/uploads/2020/11/Full-PaperMETHODOLOGY-OF-APPLICATIONGAMES-IN-THE-TRAINING-OF-YOUNGATHLETES.pdf

2. M.J.Abdullayev, A.T., O.Yu. // Improving Methodology Of Action Games In Training Athletes Of Different Ages. European Journal of Molecular \& Clinical Medicine, 2021, Volume 8, Issue 1, Pages 806-813. https://ejmcm.com/article_6556.html

3. M.J.Abdullayev, O.I. Berdiyev, N.R. Omonova. Methodology Of Organization Of" Physical Education And Sports" Lessons In Higher Educational Institutions//The American journal of social science and education innovations (TAJSSEI) SJIF-5.857 DOI10.37547/TAJSSEI Volume 3 Issue 02, 2021 ISSN 2689-100X. 3 (02), 312-320. https://usajournalshub.com/index.php/taj ssei/article/view/2214/2105

4. Rasulovich Rakhmonov Rauf. Distribution of training loads at the stage of competitive preparation for middle runners. ACADEMICIA: 
INTERNATIONAL MULTIDISCIPLINARY

RESEARCH JOURNAL. 11(2) Pg: 744-753,

Published: $\quad$ Feb 2021.

https://www.indianjournals.com/ijor.aspx

?target=ijor:aca\&volume=11\&issue $=2 \&$ arti

cle $=123$

5. S.S.Tajibaev, M.J.Abdullaev, A.T.Niyazov, O.YuNiyazova. This article scientifically analyzes and substantiates the methodology of using movement games in the development of physical and psychological training of 11-12-year-old athletes in the primary training group //European Journal of Molecular \& Clinical Medicine,2020, Volume 7, Issue 6, Pages 2907-2914.

https://ejmcm.com/article_5608_3a56479 f513a4dc5aab3431fbae4dacb.pdf 